JPDN ISSN 2579-6461 (Online) ISSN 2460-6324 (Print)

Jurnal Pendidikan Dasar Nusantara

Volume 5 | Nomor 2 | Januari 2020|

DOI: https://doi.org/10.29407/jpdn.v5i2.14238

\title{
IMPLEMENTASI MODEL PEMBELAJARAN GAL'PERIN UNTUK MENINGKATKAN AKTIVITAS DAN KEMAMPUAN BERFIKIR KRITIS MAHASISWA PADA PEMBELAJARAN STATISTIKA
}

\author{
Bambang Soenarko' ${ }^{1}$, Abdul Aziz Hunaifi², Kukuh Andri Aka ${ }^{3}$ \\ bambangsoenarko@gmail.com¹, azizhunaifi@gmail.com², \\ kukuh.andri@unpkediri.ac.id ${ }^{3}$ \\ PGSD, FKIP, Universitas Nusantara PGRI Kediri ${ }^{123}$
}

\begin{abstract}
Abstrak: Penelitian ini merupakan penelitian tindakan kelas untuk mengetahui proses keterlaksanaan model Gal'Perin, hasil peningkatan aktivitas dan kemampuan berfikir kritis (KBK) mahasiswa. Berdasarkan penelitian tindakan kelas selama 2 siklus ditemukan bahwa bahwa keterlaksanaan pembelajaran oleh dosen model menggunakan model Gal'Perin dikatakan telah $100 \%$ berhasil. Untuk keaktifan mahasiswa menunjukan di atas skor $\geq 75 \%$ dan dapat dikatakan mahasiswa aktif. Skor rata-rata keaktifan belajar siswa dari siklus I selalu menunjukkan peningkatan dibanding pertemuan-pertemuan sebelumnya. Skor siklus I mencapai 72 dan siklus II mencapai 79. Rata-rata KBK sebagai wujud hasil belajar mahasiswa secara klasikal pada siklus 1 sejumlah 79 dan pada siklus 2 sejumlah 82, meski mengalami kenaikan namun tidak menunjukkan perbedaan yang signifikan hal tersebut terbukti dari uji paired t-tes dengan hasil Sig. (2-tailed) sebesar 0,149 yang artinya lebih besar dari 0,05, maka dapat diambil kesimpulan bahwa tidak terdapat perbedaan yang signifikan antara hasil KBK siklus 1 dan siklus 2 .
\end{abstract}

Kata kunci: Gal'Perin, aktivitas, berfikir kritis, statistika.

\section{IMPLEMENTATION OF GAL'PERIN LEARNING MODEL TO IMPROVE STUDENT ACTIVITY AND CRITICAL THINKING ABILITY IN STATISTICS LEARNING}

\begin{abstract}
This research is a classroom action research study of the Gal'Perin model implementation process, the results of performance improvement and critical thinking skills (CBC) of students. Based on classroom action research for 2 cycles, it was found that the implementation of learning by the model lecturers using the Gal'Perin model had been $100 \%$ successful. Active students show scores above $\geq 75 \%$ and can be given active students. The average score of students' learning activeness from cycle I always shows improvement compared to previous meetings. Cycle I scores reach 72 and Cycle II reaches 79. The average $\mathrm{CBC}$ as a form of student learning outcomes classically in cycle 1 consists of 79 and in cycle 2 amounts to 82, thereby increasing the increase that does not show a significant difference what is evident from paired tests t-test with Sig. (2-
\end{abstract}


Bambang, Abdul, Kukuh. Implementasi Model Pembelajaran Gal'perin... tailed) of 0.149 , which means greater than 0.05 , then conclusions can be drawn that are not significantly different between the results of KBK cycle 1 and cycle 2 .

Keywords: Gal'Perin, activity, critical thinking, statistics.

\section{PENDAHULUAN}

Mata kuliah statistika adalah mata kuliah yang harus dikuasai oleh setiap mahasiswa pada jenjang pendidikan sarjana strata satu (S1). Hal tersebut dikarenakan nantinya mahasiswa pada semester akhir dapat memiliki bekal dalam hal penyusunan tugas akhir, yakni penyusunan skripsi. Mata kuliah ini tidak hanya membahas teori-teori saja, namun lebih kearah mata kuliah penerapan, sehingga mahasiswa dapat mengimplementasikan pada ranah praktik.

Pada mata kuliah statistika, banyak dibahas mengenai konsep-konsep yang berkaitan dengan pengolahan data-data, baik berupa deskriptif maupun inferensial. Melalui penguasaan konsep statistika, mahasiswa diharapkan dapat terlatih untuk berfikir teliti, cermat, logis, kritis, analitik, dan menerapkan praktik konsep statistika untuk melaksanakan tugas atau pekerjaan dalam berbagai bidang kehidupan.

Menurut Riduwan (2013) statistika merupakan suatu ilmu pengetahuan yang berkaitan dengan data statistik, yang dimulai dari kegiatan pengumulan data, teknik pengolahan data, teknik analisis data, penarikan kesimpulan, dan pembuatan kebijakan/ keputusan hasil dari penarikan kesimpulannya. Sesuai dengan kondisi perkembangan yang ada, dimana statistika sebagai konsep dan metode memiliki peran penting dalam pengolahan data dan pengambilan kesimpulan dalam situasi adanya ketidak pastian dan variasi, maka Soejoeti (1985:2) memberikan rumusan yang lebih mendalam tentang makna statistika bahwa "statistika adalah sekumpulan konsep dan metode yang digunakan untuk mengumpulkan dan menginterpretasi data tentang bidang kegiatan tertentu dan mengambil kesimpulan dalam situasi dimana ada ketidak-pastian dan variasi". Jadi, Selama mempelajari statistika, mahasiswa dituntut agar dapat menguasai konsep melalui pemahaman dengan pemikiran, penyelidikan, penemuan konsep secara mandiri, dan mengaplikasikan dalam praktik.

Oleh karena itu kehadiran statistika sebagai suatu cabang ilmu tersendiri sangat diperlukan, yang dalam perkembangan selanjutnya statistika semakin penting dalam perkembangan ilmu dan teknologi, karena merupakan landasan untuk merumuskan 
Bambang, Abdul, Kukuh. Implementasi Model Pembelajaran Gal'perin... sebuah penemuan ilmiah (Soenarko, 1993). Hal ini sebagaimana ditegaskan Siregar (2012) bahwa peranan ilmu statistik semakin penting, hampir seluruh kebijakan atau keputusan yang diambil oleh pakar didasari oleh ilmu statistic.

Dalam kenyataannya (observasi perkuliahan statistika, tanggal 12 september 2019, mahasiswa tingkat 3 prodi PGSD UN PGRI Kediri), pembelajaran statistika yang efektif belum nampak muncul. Selama pelaksanaan pembelajaran, mahasiswa terlihat kurang mempersiapkan diri sebelum dan selama pembelajaran, bahkan tugas-tugas yang diberikan oleh dosen tidak secara maksimal dikerjakan oleh mahasiswa. Sebagian besar mahasiswa ditemui lebih menggantungkan kepada temannya, seperti mencontek. Kurang persiapan dan keseriusan mahasiswa berakibat menurunnya proses belajar yang cenderung pasif dengan tingkat partisipasi yang sangat rendah dalam setiap kegiatan. Disamping itu, terlihat pula bahwa permasalahan kurangnya minat mahasiswa untuk belajar, tampak pula ekspresi kebosanan ketika mengikuti proses pembelajaran, kurang konsentrasi, akhirnya menimbulkan ketidak pahaman mahasiswa pada materi yang diajarkan, bahkan juga tidak tahu apa yang harus dipertanyakan kepada dosen.

Mahasiswa ditengarai kurang memiliki motivasi dalam belajar, hal ini diduga dilatarbelakangi adanya pemikiran negatif yang menganggap semua materi ada di internet padahal materi statistika tidak cukup untuk dipahami, namun juga dipraktikan, dengan demikian dalam konteks pembelajaran, mahasiswa terkesan malas dalam mempelajari segala sesuatu saat belum benar-benar dibutuhkan, sehingga jelas sekali dampaknya bahwa keaktifan belajar mahasiswa rendah, dan sebagai akibatnya kemampuan berpikir kritis mahasiswa tersebut juga lemah.

Keadaan di atas didukung oleh data dari hasil tugas-tugas, hasil Ujian Tengah Semester (UTS), maupun hasil Ujian Akhir Semester (UAS). Sebagaimana diketahui, belajar statistika tidak dapat dilakukan dengan sistem kebut semalam, namun harus melalui proses berfikir yang cermat, teliti, logis, kritis, analisis, sistematis, dengan melalui latihan-latihan dan pembiasaan-pembiasaan melalui tugas-tugas. Melalui proses latihan-latihan inilah diharapkan dapat mengembangkan kemampuan berpikir yang teliti, cermat, logis, kritis, dan analitis. Jika hal tersebut tidak sering diasah, maka sebagai akibat akhir yaitu hasil beajar mahasiswa berada di bawah Kriteria Ketuntasan Minimal/ (KKM) yang telah ditetapkan sebelumnya. 


\section{Bambang, Abdul, Kukuh. Implementasi Model Pembelajaran Gal'perin...}

Diakui bahwa mahasiswa prodi PGSD yang menempuh mata kuliah statistika memang tidak ditujukan kepada mereka untuk menjadi ahli statistika, namun minimal diharapkan agar mahasiswa (1) dapat mengerti dan memahami beberapa istilah dalam statistika dan manfaatnya; (2) mampu menggunakan statistika (sebagai alat bantu) dalam penyusunan laporan penelitian/ pendidikan, (3) mampu menerapkan rumus-rumus dan teknik-teknik analisis statistic dalam kegiatan penelitian/ penulisan skripsi, (4) memiliki sikap kritis, teliti dan cermat dalam menerima dan mengemukakan sesuatu, dan (5) semakin memeperoleh pemahaman dalam kaitanya dengan penguasaan mata kuliah evaluasi belajar dan penelitian pendidikan Soenarko (1993).

Selanjutnya terkait dengan persoalan di atas, maka kembali pada pemikiran bahwa dalam menciptakan pembelajaran yang efektif pengajar harus bisa memilih pola pembelajaran yang tepat sehingga mahasiswa dapat terlibat aktif dalam proses pembelajaran. Salah satu pola atau model yang dimungkinkan untuk mewujudkan pembelajaran efektif adalah model pembelajaran Gal'Perin yang merupakan gabungan dari beberapa metode mengajar, setidaknya selalu melibatkan penggunaan metode ceramah dan metode diskusi. Gabungan metode ini dapat meningkatkan minat dan interaksi peserta sisik serta menuntut keterlibatan peserta didik secara aktif. Melalui penggabungan metode ini, maka kelemahan yang ada dari satu metode dapat ditutup oleh metode lainnya. Adapun syntac/ Langkah model pembelajaran Gal'perin adalah sebagai berikut.

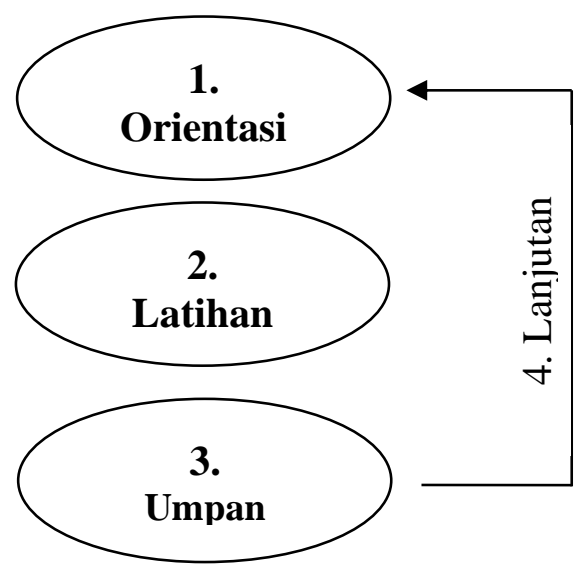

Gambar 1. Langkah Gal'perin (diadopsi Utomo, dkk., 1991)

Dalam pelaksaan pembelajaran dengan model pembelajaran Gal'perin, peserta didik bisa melakukan aktivitas mandiri, atau aktivitas dalam kelompok-kelompok kecil yang beranggotakan 2-5 orang. Menurut teori Gal'Perin ini bahwa setiap bagian 
Bambang, Abdul, Kukuh. Implementasi Model Pembelajaran Gal'perin... pendidikan harus memenuhi tiga tahapan belajar yakni (1) tahap orientasi, (2) tahap latihan, (3) umpan balik (mendiskusikan hasil latihan), dan (4) tahapan lanjutan yang pada dasarnya memperhatikan hasil umpan balik, jika belum mencapai penguasaan maka harus dilanjutkan dengan orientasi ulang, berlatih, dan seterusnya. Jika sudah mencapai penguasaan maka dilanjutkan dengan orientasi materi selanjutnya.

Keunggulan model pembelajaran Gal'Perin ini adalah bahwa dengan empat langkah dalam proses pembelajarannya yakni orientasi, latihan, umpan balik, dan tahapan lanjutan, akan menunjukkan hasil belajar yang efektif sehingga dapat membantu dalam pencapaian kemampuan pada tingkat yang lebih tinggi. Keefektifan model ini juga didukung dari hasil penelitian terdahulu oleh Ariyati (2010) dengan judul penelitian "Pembelajaran Berbasis Praktikum untuk Meningkatkan Kemampuan Berpikir Kritis Mahasiswa" dan penelitian Taqwa (2019) dengan judul "Efektivitas Pembelajaran dengan Metode Galperin terhadap Hasil Belajar Matematika Siswa SMA”.

Selain kondisi di atas, pembelajaran juga perlu dirancang untuk melatih mahasiswa berpikir secara kritis. Keterampilan berpikir selalu berkembang dan dapat dipelajari serta merupakan kecakapan yang harus dimiliki setiap orang (Arnyana, 2006). Selain itu, kemampuan berpikir juga sebagai sarana untuk kemampuan mahasiswa untuk memecahkan masalah taraf tingkat tinggi (Nasution, 2008). Peserta didik dikatakan melakukan proses berpikir kritis, jjika ia mampu mengidentifikasi, mengevaluasi, dan mengkonstruksi argumen serta mampu memecahkan masalah dengan tepat (Splitter, 1991).

Berdasarkan hal di atas, disimpulkan bahwa berpikir kritis adalah suatu proses kemampuan untuk memecahkan masalah berdasarkan pertimbangan yang baik serta pengalaman-pengalaman yang sesuai dengan fakta yang ada, sehingga dapat diambil suatu keputusan yang terbaik yang dapat dilaksanakan, yang indikator utamanya adalah kemampuan dalam menyelesaikan masalah/tugas.

Kemampuan berpikir kritis ini dapat dilatihkan di sekolah manapun melalui suatu proses belajar. Suatu proses pembelajaran dapat tercapai serta dapat meningkatkan kemampuan berpikir kritis dalam memecahkan masalah dalam proses belajar, yang pada intinya berpusat pada siswa. Adapun tahapan yang dapat ditempuh untuk mencapai kemampuan berpikir kritis dimulai dari mendefinisikan masalah dengan jelas, mencoba mengeksplorasi masalah-masalah yang ada dan yang terkait, mencoba mencarikan solusi- 
Bambang, Abdul, Kukuh. Implementasi Model Pembelajaran Gal'perin....

solusi yang mungkin dapat digunakan, dan menilai/mengevaluai penerapannya, untuk kemudian mengintegrasikannya. Disamping itu, kemampuan berpikir kritis dapat dipandang sebagai kemampuan yang mencakup seluruh aspek pengetahuan, sikap dan keterampilan untuk menganalisis dan mengevaluasi serta mensintesis sesuatu guna mengambil suatu keputusan untuk menerima atau menolak suatu pernyataan yang bersifat benar atau salah, dengan didukung alasan logis.

Selanjutnya sebagaimana diungkapkan pada paparan sebelumnya bahwa kemampuan beripikir kritis ini merupakan wujud hasil belajar peserta didik, yang dapat diungkap/dideteksi pengajar setelah peserta didik memperoleh pengalaman belajar. Hasil belajar dimaksud meliputi perubahan tersebut berupa kecakapan ilmu pengetahuan dan keterampilan yang diperoleh dari kegiatan-kegiatan yang dilakukan dengan sungguhsungguh dan pada waktu tertentu. Hasil belajar adalah perubahan perilaku secara keseluruhan bukan hanya salah satu aspek potensi kemanusiaan saja. Hasil belajar ini merupakan tingkat keberhasilan siswa/ mahasiswa dalam mempelajari materi pelajaran/ materi perkuliahan yang diperoleh dari hasil tes, yang hasilnya dinyatakan dalam bentuk skor (angka/ huruf).

Cara lain yang dilakukan untuk mengembangkan kemampuan berpikir kritis pada mahasiswa dalam penelitian ini adalah dengan memberikan pertanyaan bermakna, yaitu yang memiliki sifat produktif, imajinatif dan terbuka (USAID, 2014). Pada penelitian ini hanya dirumuskan pada sifat produktif, karena sifat materi statistika yang menjadi ilmu pasti.

Berdasarkan paparan di atas, maka perlu dilakukan penelitian tentang "Implementasi Model Pembelajaran Gal'perin untuk Meningkatkan Aktivitas dan Kemampuan Berfikir Kritis Mahasiswa pada Pembelajaran Statistika”. Dari judul tersebut diajukan tiga tujuan penelitian, yaitu (1) untuk mendeskripsikan keterlaksanaan pembelajaran menggunakan model Gal'perin pada pembelajaran Statistika, (2) untuk mendeskripsikan implementasi model pembelajaran Gal'perin dalam mata kuliah Statistika dapat mendukung terwujudnya keaktifan belajar mahasiswa prodi PGSD Universitas Nusantara PGRI Kediri, dan (3) untuk mendeskripsikan implementasi model pembelajaran Gal'perin dalam mata kuliah Statistika dapat mendukung berkembangnya kemampuan berpikir kritis sebagai wujud hasil belajar mahasiswa prodi PGSD Universitas Nusantara PGRI Kediri. 
Bambang, Abdul, Kukuh. Implementasi Model Pembelajaran Gal'perin...

\section{METODE}

\section{Jenis Penelitian}

Jenis penelitian yang digunakan adalah penelitian tindakan kelas (PTK) yang bersifat reflektif, partisipatif, kolaboratif, dan spiral, bertujuan untuk melakukan perbaikan-perbaikan terutama pada keaktifan belajar, kemampuan berpikir kritis sebagai wujud hasil belajar.

Penelitian Tindakan Kelas adalah penelitian yang mengangkat masalah-masalah actual yang dilakukan oleh guru/pendidik/dosen yang merupakan pencermatan kegiatan belajar berupa tindakan untuk memperbaiki dan meningkatkan praktik pembelajaran di kelas secara lebih professional (Tanireja, dkk., 2012). Desain penelitian ini menggunakan desain model Kemmis dan Mc Taggart (1992), terdiri dari tahapan sebagai berikut: a. Penyusunan perencanaan (Planning); b. Pelaksanaan tindakan (Acting); c. Observasi (Observing); d. Refleksi (Reflecting), yang dapat digambarkan berikut ini.

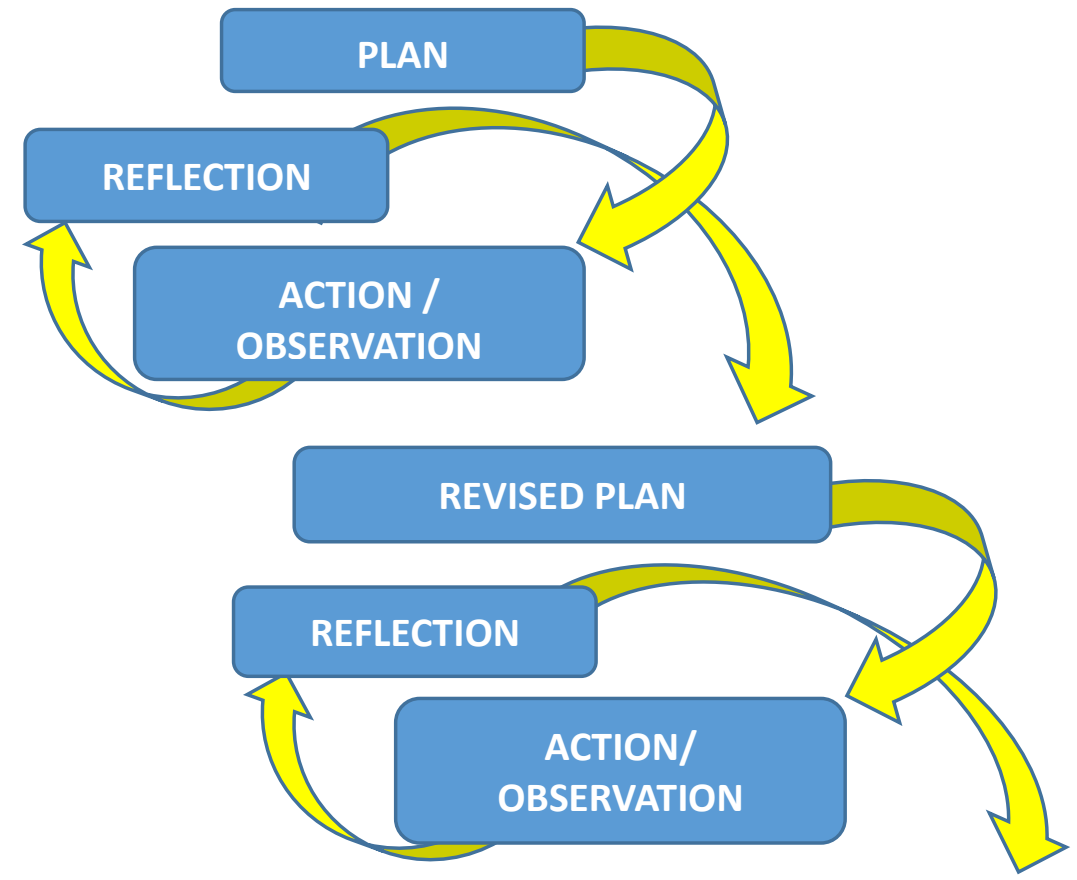

Gambar 1. Desain PTK model Kemmis dan Mc Taggart (1992)

\section{Subjek dan Setting Penelitian}

Penelitian dilaksanakan di Universitas Nusantara PGRI Kediri, pada Fakultas Keguruan dan Ilmu Pendidikan, Program Studi Pendidikan Guru Sekolah Dasar, dengan 
Bambang, Abdul, Kukuh. Implementasi Model Pembelajaran Gal'perin... sasaran penelitian pada mahasiswa kelas A angkatan tahun 2017 pada semester $\mathrm{V}$ tahun akademik 2019-2020.

\section{Kehadiran Peneliti}

Pada penelitian ini, peneliti sekaligus berperan sebagai pengajar dan merencanakan dan melaksanakan kegiatan berikut :

1. Menyusun RPS mata kuliah Statistika-1

2. Menyusun instrumen terkait dengan variabel keaktifan belajar mahasiswa, dan kemampuan berpikir kritis sebagai wujud hasil belajar mahasiswa

3. Melaksanakan pembelajaran/ perkuliahan dengan mengimplementasikan model pembelajara Gal'perin

4. Mengumpulkan data dengan cara mengamati kegiatan pembelajaran (yang bekerjasama dengan kolaborator)

5. Melaporkan hasil penelitian

\section{Prosedur Pengumpulan Data}

Sesuai dengan tujuan penelitian yang diteliti, data yang diukur meliputi (1) keterlaksanaan pembelajaran menggunakan model Gal'perin, (2) aspek keaktifan belajar mahasiswa, dan (3) hasil belajar mahasiswa terkait kemampuan berfikir kritis, maka pengumpulan data pada penelitian ini dilakukan dengan menggunakan teknik sebagai berikut :

\section{Observasi}

Observasi dalam hal ini digunakan untuk menghimpun data tentang keterlaksanaan pembelajaran menggunakan model Gal'perin oleh dosen model dan keaktifan belajar mahasiswa, yang akan diobservasi oleh dua orang observer.

\section{Pelaksanaan Tugas dan Tes}

Tugas dan tes ini meliputi tugas/tes individu ataupun kelompok, maupun tugastugas/ tes yang dikerjakan di kelas ataupun tugas yang dilaksanakan di rumah, yang dimaksudkan untuk menghimpun data tentang kemampuan berpikir kritis sebagai wujud hasil belajar mahasiswa setelah pemberian tindakan. Tugas-tugas tersebut memiliki sifat produktif (USAID, 2014).

\section{Teknik Analisis Data}

Secara procedural, sebelum data di refleksikan, maka data-data diolah disusun dalam tebel atau grafik sehingga memudahkan untuk dibaca dan diseskripsikan. 
Bambang, Abdul, Kukuh. Implementasi Model Pembelajaran Gal'perin...

Selanjutnya sesuai dengan data-data yang akan dihimpun, selanjutnya akan dianalisis menggunakan teknik analisis deskriptif kuantitatif dan t-Test, yang dapat ditegaskan sebagai berikut.

\section{Tabel 1. Teknik Analisis Data}

\begin{tabular}{|c|l|l|}
\hline No & \multicolumn{1}{|c|}{ Hipotesis } & \multicolumn{1}{|c|}{ Teknik Analisis } \\
\hline 1 & $\begin{array}{l}\text { Keterlaksanaan pembelajaran menggunakan model Gal'perin } \\
\text { pada pembelajaran Statistika }\end{array}$ & $\begin{array}{l}\text { Membandingkan hasil observasi } \\
\text { keterlaksanaan pembelajaran dengan } \\
\text { kriteria minimum keterlaksaan 75\% }\end{array}$ \\
\hline 2 & $\begin{array}{l}\text { Implementasi model pembelajaran Gal'perin dalam mata } \\
\text { kuliah Statistika dapat mendukung terwujudnya keaktifan } \\
\text { belajar mahasiswa prodi PGSD Universitas Nusantara PGRI } \\
\text { Kediri }\end{array}$ & $\begin{array}{l}\text { Membandingkan tingkat keaktifan dari } \\
\text { setiap siklus }\end{array}$ \\
\hline 3 & $\begin{array}{l}\text { Implementasi model pembelajaran Gal'perin dalam mata } \\
\text { kuliah Statistika dapat mendukung berkembangnya } \\
\text { kemampuan berpikir kritis sebagai wujud hasil belajar } \\
\text { mahasiswa prodi PGSD Universitas Nusantara PGRI Kediri }\end{array}$ & $\begin{array}{l}\text { Membandingkan kemampuan berpikir } \\
\text { kritis dari setiap siklus dan untuk } \\
\text { memperoleh keyakinan dianalisis } \\
\text { dengan statistik paired t-Test }\end{array}$ \\
\hline
\end{tabular}

Kriteria keberhasilan tindakan ditetapklan dengan kriteria sebagai berikut:

1. Untuk keterlaksanaan pembelajaran menggunakan model Gal'perin, ditetapkan kriteria keterlaksaan minimal $75 \%$

2. Untuk tingkat keaktifan belajar, ditetapkan dengan kriteria minimal pada skor 75 , sedang capaian klasikal ditetapkan minimal $75 \%$ aktif

3. Untuk kemampuan berpikir kritis sebagai wujud hasil belajar, ditetapkan kriteria minimal dengan skor 75, sedang capaian klasikal ditetapkan minimal 75\%

Data keterlaksanaan pembelajaran menggunakan model Gal'perin diolah secara kualitatif dengan mencari presentasenya dengan rumus:

Keberhasilan tindakan dosen model $=\sum$ skor perolehan $/ \sum$ skor maksimal (16) $\mathrm{x}$ 100\%. Tiap aspek (total 8 item) diamati dalam 3 skala, yaitu skor 0 jika tidak terlihat sama sekali, skor 1 jika terlihat namun kurang lengkap, skor 2 jika terlihat secara lengkap. Adapun aspek yang diamati untuk mengukur keberhasilan tindakan dosen dapat dilihat seperti tabel di bawah ini.

Tabel 2. Pengembangan Komponen Sintaks Gal'perin pada Pembelajaran Statistika sebagai Acuan Keterlaksanaan Tindakan

\begin{tabular}{|c|c|}
\hline Aspek Yang Diamati & Indikator \\
\hline \multirow[t]{3}{*}{ Orientasi } & 1. Apersepsi \\
\hline & $\begin{array}{l}\text { 2. Menyampaian kompetensi, tujuan pembelajaran, dan } \\
\text { langkah pembelajaran }\end{array}$ \\
\hline & 3. Menyampaikan materi pengantar \\
\hline \multirow[t]{2}{*}{ Latihan } & 4. Memberikan tugas latihan kepada mahasiswa \\
\hline & $\begin{array}{l}\text { 5. Membimbing mahasiswa dalam mengerjakan tugas } \\
\text { latihan }\end{array}$ \\
\hline
\end{tabular}


Bambang, Abdul, Kukuh. Implementasi Model Pembelajaran Gal'perin...

\begin{tabular}{|l|l|}
\hline \multirow{2}{*}{ Umpan Balik } & $\begin{array}{l}\text { 6. Melakukan tanya jawab terkait kendala-kendala } \\
\text { mahasiswa }\end{array}$ \\
\cline { 2 - 2 } Lanjutan & $\begin{array}{l}\text { 7. Memberikan soal-soal umpan balik } \\
\text { orientasi untuk materi-materi tertentu) }\end{array}$ \\
\hline
\end{tabular}

Sumber: Utomo, dkk., 1991

Untuk data tentang aktivitas belajar mahasiswa menggunakan rumus sebagai berikut:

Skor aktivitas belajar mahasiswa $=\sum$ skor perolehan $/ \sum$ skor maksimal (16) $\mathrm{x}$ $100 \%$

$\mathrm{n} 1=$ skor aspek pemecahan masalah (4 indikator)

$\mathrm{n} 2=$ skor aspek kerjasama (4 indikator)

$\mathrm{n} 3=$ skor aspek mengemukakan gagasan (5 indikator)

$\mathrm{n} 4=$ skor aspek perhatian (3 indikator)

dari hasil tiap mahasiswa akan dicari persentase klasikalnya dengan menghitung rata-rata skor aktivitas belajar siswa dalam satu kelas. Adapun aspek-aspek di atas diamati dalam 5 skala.

Untuk menganalisis hasil belajar siswa setelah pembelajaran menggunakan rumus rata-rata:

$$
\bar{x}=\frac{\sum \text { seluruh skor siswa }}{\sum \text { siswa }} \times 100 \%
$$

$\bar{x}=$ skor persentase rata-rata hasil belajar siswa klasikal

\section{Rencana Jadwal Penelitian}

Sesuai dengan ketersediaan waktu dan jadwal perkuliahan yang ada, maka rencana kegiatan penelitian dirancang sebagaimana pada tabel 2 berikut.

Tabel 3. Rencana Kegiatan Penelitian

\begin{tabular}{|c|c|c|c|c|c|c|c|c|c|c|c|c|c|}
\hline \multirow{2}{*}{ No } & \multirow{2}{*}{ Kegiatan } & \multicolumn{4}{|c|}{ Agustus 2019} & \multicolumn{4}{|c|}{ September 2019} & \multicolumn{4}{|c|}{ Oktober 2019} \\
\hline & & 1 & 2 & 3 & 4 & 1 & 2 & 3 & 4 & 1 & 2 & 3 & 4 \\
\hline 1 & $\begin{array}{l}\text { Penyusunan Rencana } \\
\text { Penelitian Tindakan }\end{array}$ & & & & & & & & & & & & \\
\hline 2 & Pengembangan Instrumen & & & & & & & & & & & & \\
\hline 3 & $\begin{array}{l}\text { Pelaksanaan Tindakan } 1 \text { dan } \\
2 \text { (siklus I) }\end{array}$ & & & & & & & & & & & & \\
\hline 4 & $\begin{array}{l}\text { Pelaksanaan Tindakan } 1 \text { dan } \\
2 \text { (siklus II) }\end{array}$ & & & & & & & & & & & & \\
\hline 5 & Penyusunan Laporan & & & & & & & & & & & & \\
\hline Kete & 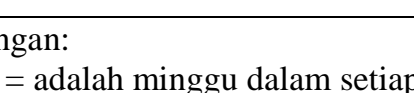 & & & & & & & & & & & & \\
\hline
\end{tabular}


Bambang, Abdul, Kukuh. Implementasi Model Pembelajaran Gal'perin...

Tiap 1 siklus meliputi 2 pertemuan pembelajaran

\section{HASIL}

Data yang diperoleh pada penilitian ini merupakan hasil pelaksanaan pembelajaran yang dilakukan selama dua siklus. Setiap siklus terdiri dari dua kali pertemuan. Di bawah ini dapat dilihat uraian data pada penelitian ini.

Keterlaksanaan Pembelajaran Menggunakan Model Gal'perin pada Pembelajaran Statistika

Tabel 4. Rekapitulasi Data Keterlaksanaan Pembelajaran Menggunakan Model Gal'perin pada Pembelajaran Statistika

\begin{tabular}{|c|c|c|c|c|c|}
\hline \multirow{3}{*}{$\begin{array}{l}\text { Aspek Yang } \\
\text { Diamati }\end{array}$} & \multirow{3}{*}{ Indikator } & \multicolumn{4}{|c|}{ Skor Keterlaksanaan Pembelajaran tiap Pertemuan } \\
\hline & & \multicolumn{2}{|c|}{ Siklus 1} & \multicolumn{2}{|c|}{ Siklus 2} \\
\hline & & Pertemuan 1 & Pertemuan 2 & Pertemuan 1 & Pertemuan 2 \\
\hline \multirow{3}{*}{ Orientasi } & 1. Apersepsi & 2 & 2 & 2 & 2 \\
\hline & $\begin{array}{l}\text { 2. Menyampaian kompetensi, } \\
\text { tujuan pembelajaran, dan } \\
\text { langkah pembelajaran }\end{array}$ & 2 & 2 & 2 & 2 \\
\hline & $\begin{array}{l}\text { 3. Menyampaikan materi } \\
\text { pengantar }\end{array}$ & 2 & 2 & 2 & 2 \\
\hline \multirow[b]{2}{*}{ Latihan } & $\begin{array}{l}\text { 4. Memberikan tugas latihan } \\
\text { kepada mahasiswa }\end{array}$ & 2 & 2 & 2 & 2 \\
\hline & $\begin{array}{l}\text { 5. Membimbing mahasiswa } \\
\text { dalam mengerjakan tugas } \\
\text { latihan }\end{array}$ & 2 & 2 & 2 & 2 \\
\hline \multirow{2}{*}{$\begin{array}{l}\text { Umpan } \\
\text { Balik }\end{array}$} & $\begin{array}{l}\text { 6. Melakukan tanya jawab } \\
\text { terkait kendala-kendala } \\
\text { mahasiswa }\end{array}$ & 2 & 2 & 2 & 2 \\
\hline & $\begin{array}{l}\text { 7. Memberikan soal-soal } \\
\text { umpan balik }\end{array}$ & 2 & 2 & 2 & 2 \\
\hline Lanjutan & $\begin{array}{l}\text { 8. Dosen melakukan proses } \\
\text { lanjutan (kembali ke } \\
\text { orientasi untuk materi- } \\
\text { materi tertentu) }\end{array}$ & 2 & 2 & 2 & 2 \\
\hline & Skor tiap siklus & 16 & 16 & 16 & 16 \\
\hline \multicolumn{2}{|c|}{$\begin{array}{l}\text { Persentase Skor Keterlaksanaan Pembelajaran } \\
\text { secara Utuh }\end{array}$} & $100 \%$ & $100 \%$ & $100 \%$ & $100 \%$ \\
\hline & Keterangan & Berhasil & Berhasil & Berhasil & Berhasil \\
\hline
\end{tabular}

Keterangan: Kolom keterangan dikatakan berhasil jika skor di $\geq 75 \%$ 
Bambang, Abdul, Kukuh. Implementasi Model Pembelajaran Gal'perin... Keaktifan Belajar Mahasiswa

Tabel 5. Rekapitulasi Data Keaktifan Belajar Mahasiswa

\begin{tabular}{|c|c|c||c|c|c|}
\hline Inisial & $\begin{array}{c}\text { KEAKTIFAN } \\
\text { SIKLUS-1 }\end{array}$ & $\begin{array}{c}\text { KEAKTIFAN } \\
\text { SIKLUS-2 }\end{array}$ & Inisial & $\begin{array}{c}\text { KEAKTIFAN } \\
\text { SIKLUS-1 }\end{array}$ & $\begin{array}{c}\text { KEAKTIFAN } \\
\text { SIKLUS-2 }\end{array}$ \\
\hline SL & 74 & 82 & NR & 70 & 76 \\
\hline AS & 71 & 81 & RD & 72 & 80 \\
\hline PM & 71 & 78 & EW & 77 & 78 \\
\hline NN & 72 & 80 & DA & 70 & 76 \\
\hline JZ & 77 & 85 & KU & 74 & 81 \\
\hline AM & 70 & 80 & GA & 70 & 74 \\
\hline AA & 73 & 76 & SA & 73 & 82 \\
\hline DA & 73 & 78 & AO & 72 & 77 \\
\hline DP & 70 & 75 & BS & 66 & 74 \\
\hline DI & 70 & 79 & AP & 74 & 84 \\
\hline SD & 74 & 88 & AE & 73 & 81 \\
\hline RP & 73 & 80 & LN & 68 & 79 \\
\hline AB & 72 & 79 & UN & 68 & 78 \\
\hline VT & 75 & 76 & AM & 70 & 76 \\
\hline AW & 71 & 78 & MI & 72 & \\
\hline AD & 72 & 86 & MV & 71 & 79 \\
\hline & Rata-Rata Keaktifan Secara Klasikal pada Siklus $1=72$ & \\
\hline & Rata-Rata Keaktifan Secara Klasikal pada Siklus $2=79$ & \\
\hline
\end{tabular}

\section{- Siklus 1 Siklus 2}

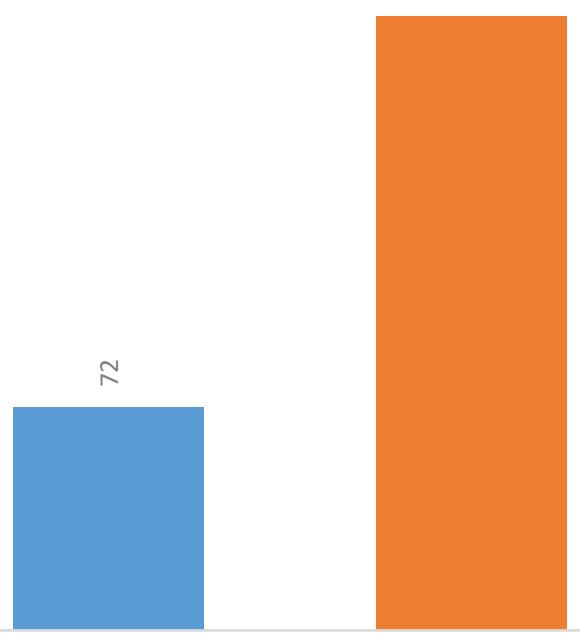

RATA-RATA KEAKTIFAN SECARA KLASIKAL

\section{Grafik 1. Data Keaktifan Belajar Mahasiswa}


Bambang, Abdul, Kukuh. Implementasi Model Pembelajaran Gal'perin...

Kemampuan Berpikir Kritis sebagai Wujud Hasil Belajar Mahasiswa

Tabel 6. Rekapitulasi Data Kemampuan Berpikir Kritis (KBK) sebagai Wujud Hasil Belajar Mahasiswa

\begin{tabular}{|c|c|c|c|c|c|}
\hline Inisial & $\begin{array}{c}\text { KBK } \\
\text { SIKLUS-1 }\end{array}$ & $\begin{array}{c}\text { KBK } \\
\text { SIKLUS-2 }\end{array}$ & Inisial & $\begin{array}{c}\text { KBK } \\
\text { SIKLUS-1 }\end{array}$ & $\begin{array}{c}\text { KBK } \\
\text { SIKLUS-2 }\end{array}$ \\
\hline SL & 70 & 83 & NR & 85 & 50 \\
\hline AS & 80 & 83 & $\mathrm{RD}$ & 90 & 50 \\
\hline PM & 80 & 83 & EW & 80 & 83 \\
\hline $\mathrm{NN}$ & 75 & 70 & $\mathrm{DA}$ & 60 & 75 \\
\hline $\mathrm{JZ}$ & 70 & 50 & $\mathrm{KU}$ & 80 & 85 \\
\hline $\mathrm{AM}$ & 15 & 50 & GA & 80 & 95 \\
\hline AA & 80 & 90 & SA & 80 & 95 \\
\hline $\mathrm{DA}$ & 65 & 50 & $\mathrm{AO}$ & 80 & 90 \\
\hline DP & 60 & 50 & BS & 80 & 100 \\
\hline DI & 60 & 80 & $\mathrm{AP}$ & 90 & 95 \\
\hline $\mathrm{SD}$ & 100 & 100 & $\mathrm{AE}$ & 90 & 100 \\
\hline $\mathrm{RP}$ & 90 & 100 & $\mathrm{LN}$ & 90 & 100 \\
\hline $\mathrm{AB}$ & 100 & 100 & UN & 90 & 100 \\
\hline VT & 90 & 75 & $\mathrm{AM}$ & 80 & 85 \\
\hline AW & 95 & 90 & MI & 90 & 95 \\
\hline $\mathrm{AD}$ & 100 & 86 & MV & 71 & 76 \\
\hline \multicolumn{6}{|c|}{$\sum$ Mahasiswa dan persentase yang tidak tuntas $(<75)$ pada siklus $1=8(25 \%)$} \\
\hline \multicolumn{6}{|c|}{$\sum$ Mahasiswa dan persentase yang tidak tuntas $(<75)$ pada siklus $2=7(22 \%)$} \\
\hline \multicolumn{6}{|c|}{$\sum$ Mahasiswa dan persentase yang tuntas $(\geq 75)$ pada siklus $1=24(75 \%)$} \\
\hline \multicolumn{6}{|c|}{$\sum$ Mahasiswa dan persentase yang tuntas $(\geq 75)$ pada siklus $2=25(78 \%)$} \\
\hline \multicolumn{6}{|c|}{ Rata-Rata KBK sebagai Wujud Hasil Belajar Mahasiswa secara Klasikal pada Siklus $1=79$} \\
\hline \multicolumn{6}{|c|}{ Rata-Rata KBK sebagai Wujud Hasil Belajar Mahasiswa secara Klasikal pada Siklus $2=82$} \\
\hline
\end{tabular}


Bambang, Abdul, Kukuh. Implementasi Model Pembelajaran Gal'perin...

$$
\text { घ Tidak Tuntas a Persentase Tidak Tuntas }
$$

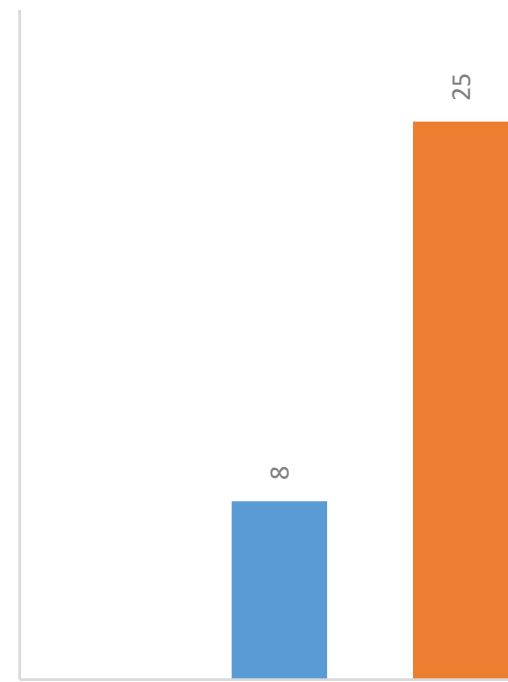

SIKLUS 1

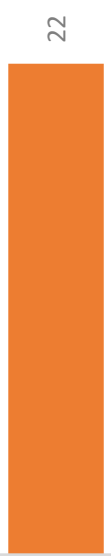

SIKLUS 2

Grafik 2. Data $\sum$ Mahasiswa dan Persentase Tidak Tuntas pada Siklus 1 dan 2

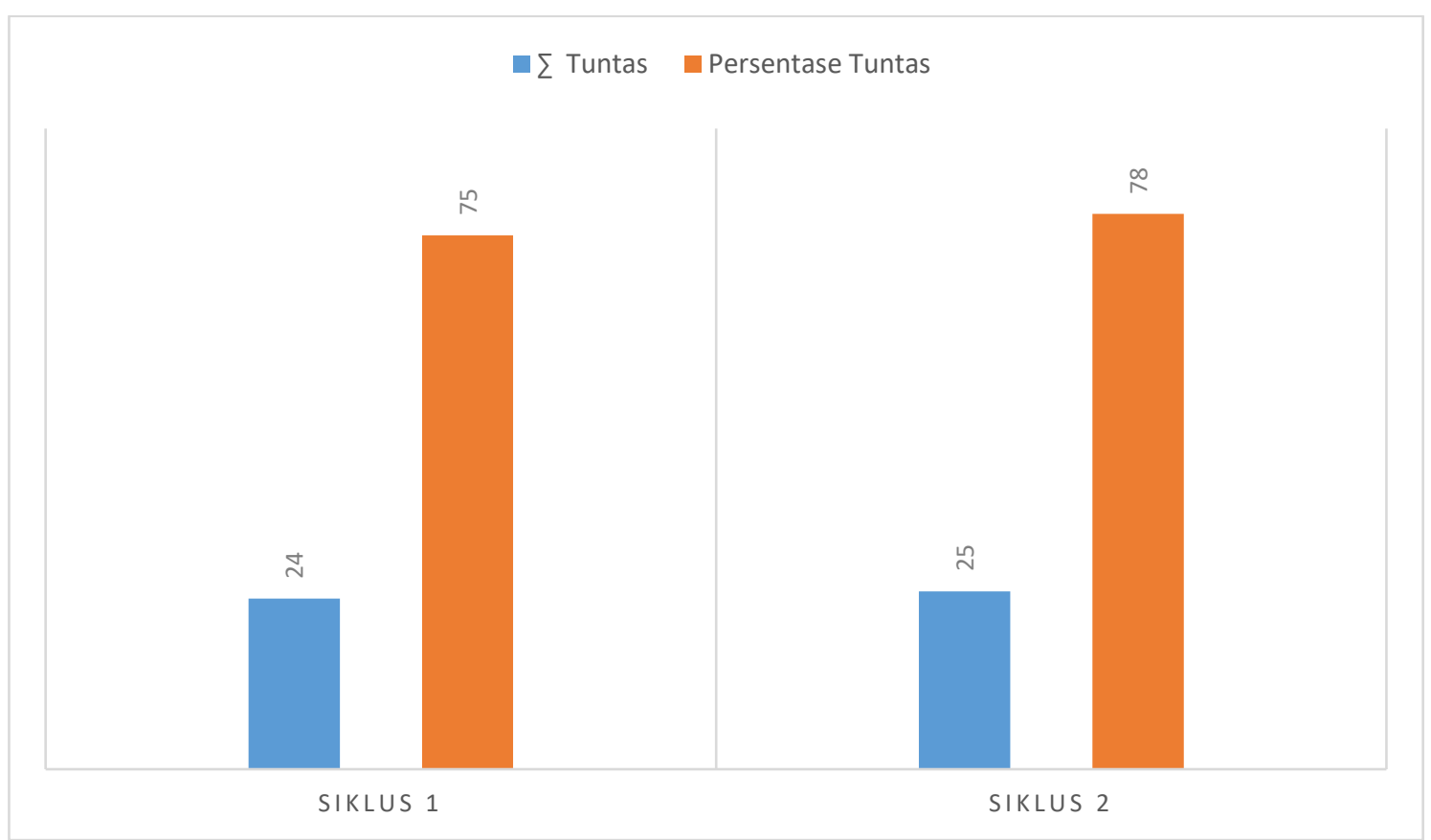

Grafik 3. Data $\sum$ Mahasiswa dan Persentase Tuntas pada Siklus 1 dan 2 


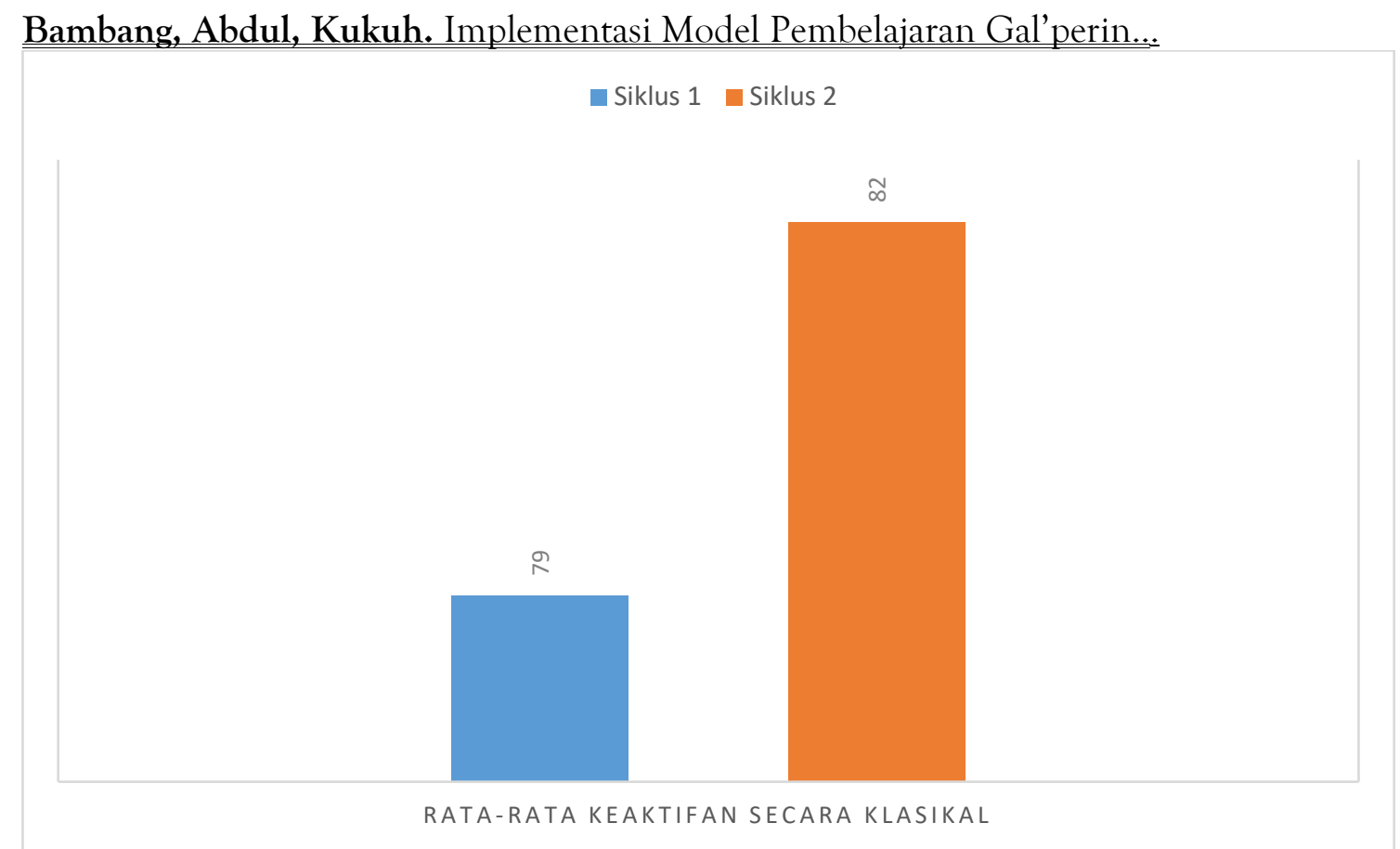

\section{Grafik 4. Data Rata-Rata Kemampuan Berfikir Kritis sebagai Wujud Hasil Belajar Mahasiswa secara Klasikal}

\section{PEMBAHASAN}

\section{Keterlaksanaan Pembelajaran Menggunakan Model Gal'perin pada Pembelajaran}

\section{Statistika}

Seperti yang dapat dilihat pada tabel 4 tentang rekapitulasi data keterlaksanaan pembelajaran menggunakan model Gal'Perin pada pembelajaran statistika, dapat diamati bahwa, skor keberhasilan dosen pada tiap pertemuan di tiap siklus berada di atas $75 \%$, yaitu skor siklus I mencapai 100\% dan siklus II mencapai 100\%, jadi penerapan pembelajaran melalui model Gal'Perin pada penelitian ini disimpulkan berhasil. Berikut uraian pelaksanaan tiap tahapnya

\section{Tahap Orientasi}

Seperti yang diketahui, pelaksanaan pembelajaran menggunakan model Gal'Perin diawali dari tahap orientasi, tahap ini dimaksudkan agar mahasiswa berorientasi terhadap unsur-unsur ilmu yang penting, termasuk cara-cara penalaran yang khas untuk bidang studi. Pada tahap ini guru model telah melakukan orientasi dengan baik dengan menyampaikan orientasi materi perkuliahan secara interaktif dan membuka sesi tanya jawab jika terlihat ada mahasiswa yang kebingungan. 

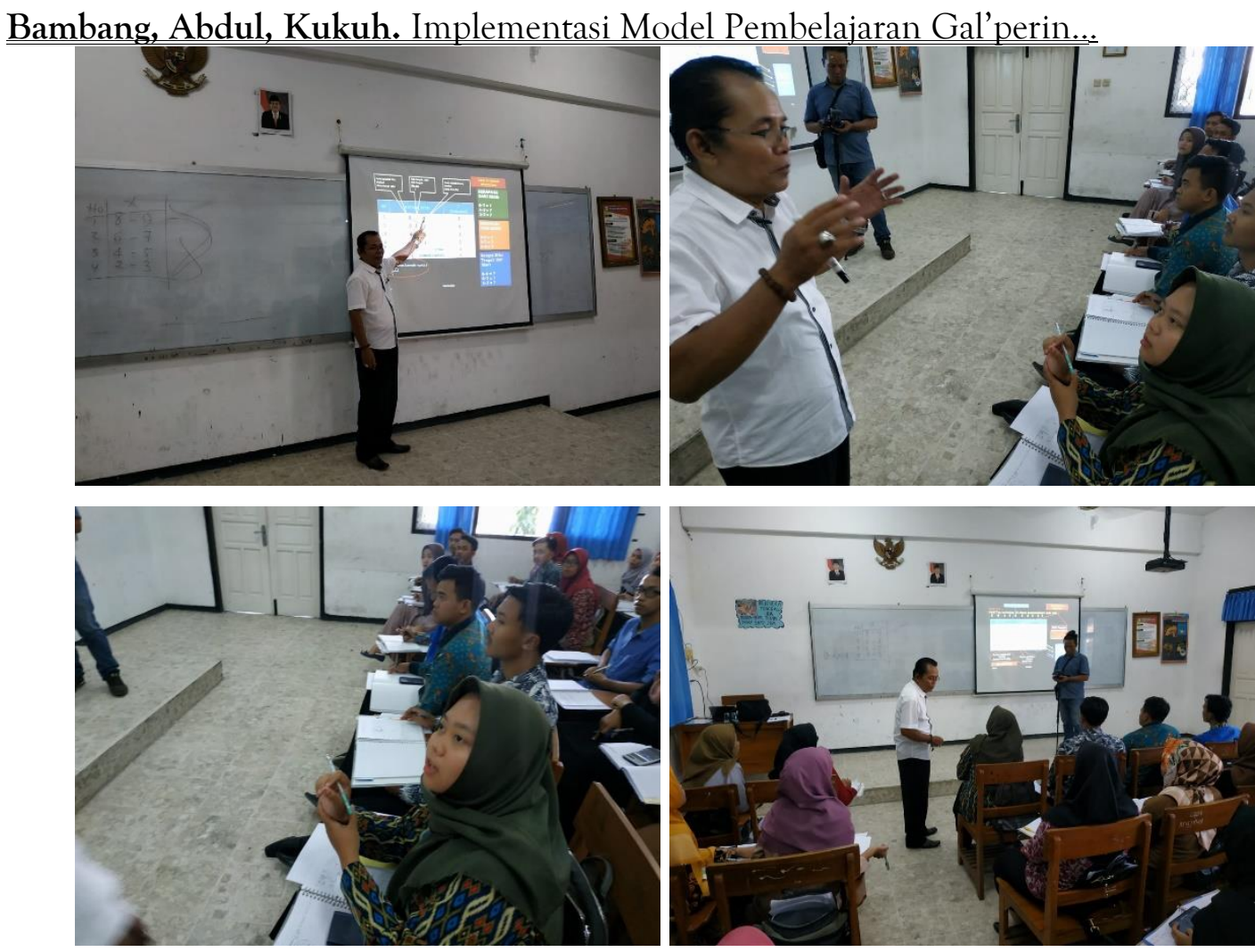

Gambar 2. Dosen Model Menyampaikan Orientasi

Selama melakukan tahap orientasi, dosen selalu menunjukkan sikap yang antusias, dengan melakukan kuliah interaktif dan menyampaiakn materi secara step by step. Dari gambar di atas, juga dapat diamati bahwa, selama dosen model melakukan orientasi tidak menutup kemungkinan dosen model untuk mendekati mahasiswa agar penjelasan lebih interaktif.

\section{Tahap Latihan}

Dalam hal ini mahasiswa diminta untuk melakukan sesuatu secara lebih konkrit, terkait dengan bahan yang digunakan dalam orientasi. Latihan ini terdiri dari tugas-tugas dan soal-soal atau demonstrasi tergantung pada tingkat pengertian yang dikehendaki.

Pada tahap latihan, dosen mengupayakan soal-soal yang diberikan kepada mahasiswa memiliki sifat : (a) kemampuan mengidentifikasi/mengenal masalah dan kejelasan masalah, dan mengenal adanya hubungan yang logis antara masalah satu dengan yang lain (masalah tidak berdiri sendiri), (b) kemampuan menyusun skala prioritas atas permasalahan yang muncul, (c) kemampuan menemukan alternatif cara yang dipakai menangani masalah-masalah itu, (d) kemampuan mengumpulkan informasi dan menyusun data yang diperlukan, (e) kemampuan mengenal asumsi-asumsi dan nilai- 
Bambang, Abdul, Kukuh. Implementasi Model Pembelajaran Gal'perin... nilai yang tidak dinyatakan, serta menginterpretasikan, yaitu mengkategorikan dan mengklasifikasi, (f) kemampuan menyusun kembali pola-pola pemikiran berdasarkan pengalaman yang lebih luas, dan menilai fakta dan mengevaluasi pernyataan-pernyataan, (g) kemampuan mengevaluasi/mempertimbangkan dan menganalisis data dan mengujinya serta menarik kesimpulan-kesimpulan diperlukan, (h) kemampuan deskriptif menggunakan bahasa yang tepat, jelas dan logis yang melahirkan argumentasi, dan (i) kemampuan kemandirian dalam menganalisis data, mengintepretasi dan menyimpulkan serta memberikan argumentasi (Rooijakkers, 1989).

Selanjutnya sebagaimana diungkapkan pada paparan sebelumnya bahwa kemampuan beripikir kritis ini merupakan wujud hasil belajar peserta didik, yang dapat diungkap/dideteksi pengajar setelah peserta didik memperoleh pengalaman belajar. Hasil belajar dimaksud meliputi perubahan tersebut berupa kecakapan ilmu pengetahuan dan keterampilan yang diperoleh dari kegiatan-kegiatan yang dilakukan dengan sungguhsungguh dan pada waktu tertentu. Hasil belajar adalah perubahan perilaku secara keseluruhan bukan hanya salah satu aspek potensi kemanusiaan saja. Hasil belajar ini merupakan tingkat keberhasilan siswa/ mahasiswa dalam mempelajari materi pelajaran/ materi perkuliahan yang diperoleh dari hasil tes, yang hasilnya dinyatakan dalam bentuk skor (angka/ huruf).

Cara lain yang dilakukan untuk mengembangkan kemampuan berpikir kritis pada mahasiswa dalam penelitian ini adalah dengan memberikan pertanyaan bermakna, yaitu yang memiliki sifat produktif, imajinatif dan terbuka (USAID, 2014). Pada penelitian ini hanya dirumuskan pada sifat produktif, karena sifat materi statistika yang menjadi ilmu pasti. Pengertian sifat produktif yaitu pertanyaan yang dikembangkan untuk diberikan pada mahasiswa adalah pertanyaan yang mendorong mahasiswa untuk melakukan kegiatan lebih lanjut (melakukan percobaan, pengamatan, penyelidikan, dan/atau eksplorasi) untuk memperoleh jawabannya. Berikut beberapa contoh soal latihan. 
Bambang, Abdul, Kukuh. Implementasi Model Pembelajaran Gal'perin...

LATIHAN
- Bersasarkan data pada tabel (Tabel
1 distribusi tunggal $\&$ tabel 2
distribusi bergolong), Jika pada
pembelajaran pertemuan pertama
diprediksi separoh akan mengikuti
program pengayaan, dan separoh
mengikuti program remidial,
berapakah batas nilai minimal
untuk bisa ikut pengayaan?

LATIHAN
(Tabel 1 distribusi tunggal \& tabel 2
distribusi bergolong), Jika tiga orang
dari kelompok tersebut akan dikirim
untuk mengikuti olympiade
matematika,
Berapakah nilai minimal yang
yang harus dicapai untuk bisa
mengikuti olympiade?

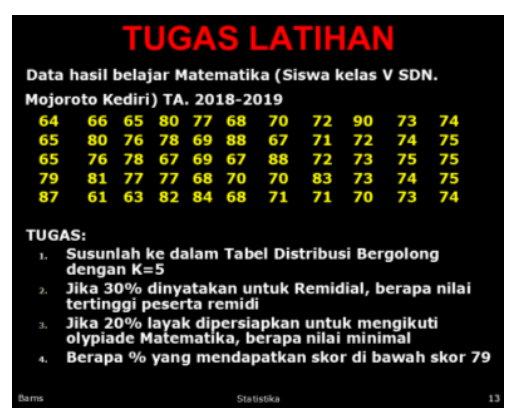

Gambar 3. Contoh Soal Latihan yang memiliki Ciri KBK yang mengharuskan mahasiswa melakukan percobaan, pengamatan, penyelidikan, dan/atau eksplorasi untuk memperoleh jawabannya
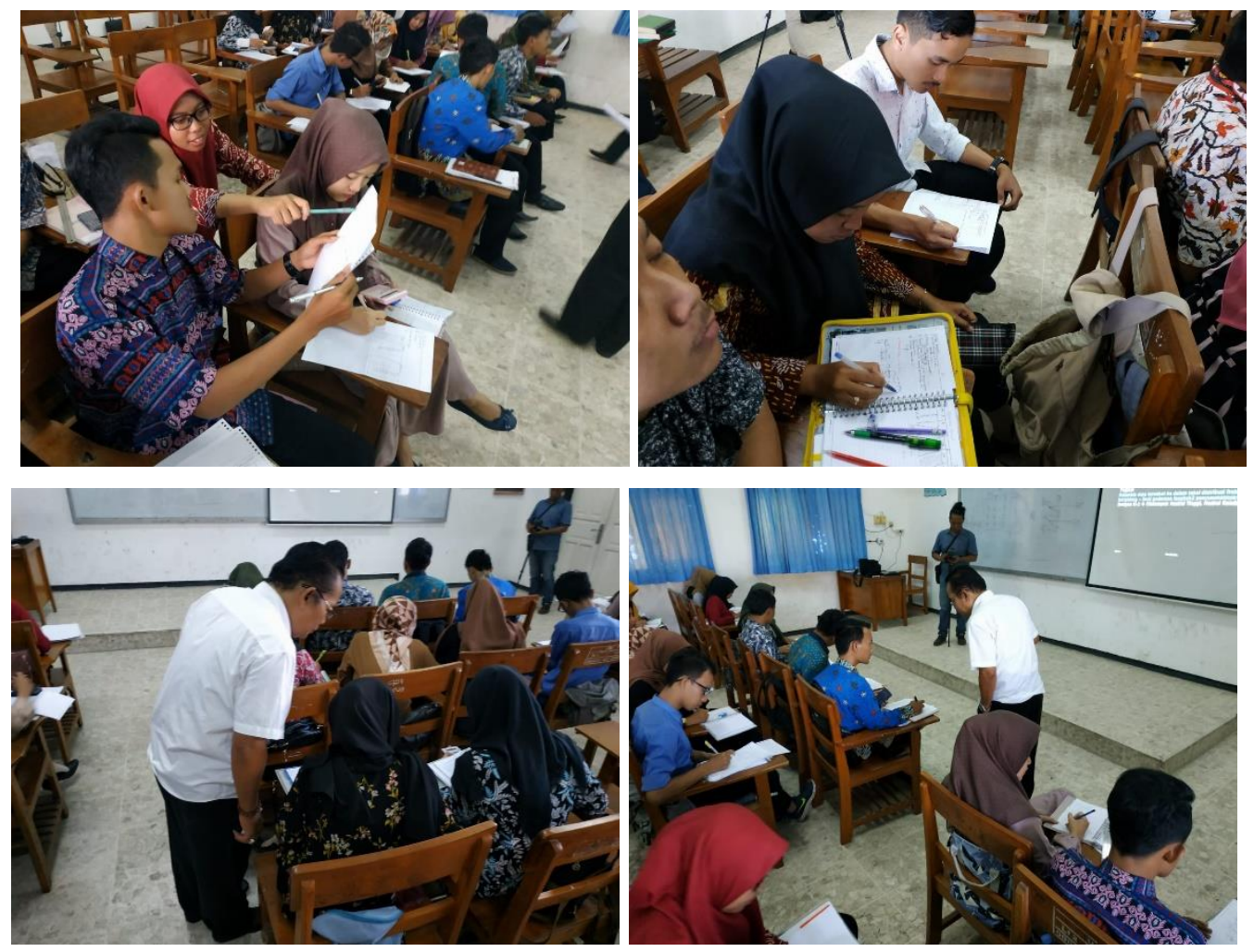

Gambar 4. Dosen Model Berkeliling Melakukan Pengamatan saat Mahasiswa Melakukan Latihan 


\section{Bambang, Abdul, Kukuh. Implementasi Model Pembelajaran Gal'perin...}

Dari 4 gambar di atas terlihat dosen model melakukan interaksi dengan mahasiswa secara baik, yaitu dosen model melakukan rotasi dan membimbing mahasiswa secara merata. Diketahui memang tahap latihan akan lebih berhasil baik kalau mahasiswa didampingi dan benar-benar dibimbing oleh dosen. Pada tahap latihan mahasiswa ditugaskan membahas soal-soal mengerti dan memahami materi kuliah yang dipelajari dan hingga mencapai tujuan perkuliahan. Pada tahap latihan ini dosen berperan sebagai fasilitator. Dosen tidak hanya duduk, tetapi juga aktif memonitor kegiatan setiap mahasiswa dalam kegiatan latihan. Dosen juga siap memberikan penjelasan seperlunya manakala ada mahasiswa yang menanyakan sesuatu yang berkaitan dengan soal atau tugasnya.

\section{Tahap Umpan Balik}

Umpan balik berisi informasi tentang hal yang dikerjakan selama latihan, latihan ini hanya mempunyai arti kalau mahasiswa diberitahu kesalahan-kesalahannya selama melakukan latihan. Umpan balik ini dapat berupa lisan atau tulisan. Dalam umpan balik ini mahasiswa diharapkan dapat mengutarakan pikirannya secara nyata (verbal dan tertulis). Pelaksanaan umpan balik dapat dilakukan selama latihan maupun sesudah latihan. Umpan balik selama latihan dapat berupa penyelesaian soal-soal sedangkan sesudah latihan berupa tes. Namun perlu dipahami bahwa umpan balik bukan merupakan penilaian.

Selama umpan balik, dosen hanya sebagai fasilitator yang bertujuan untuk mengetahui sejauh mana bahan yang telah dipelajari dapat dimengerti oleh siswa/ mahasiswa. Kegiatan umpan balik tersebut dimanfaatkan oleh guru/ dosen untuk menarik simpulan dalam mengambil langkah-langkah selanjutnya, misalnya apakah masih perlu mengulangi pelajaran atau harus melanjutkan pelajaran. 
Bambang, Abdul, Kukuh. Implementasi Model Pembelajaran Gal'perin...
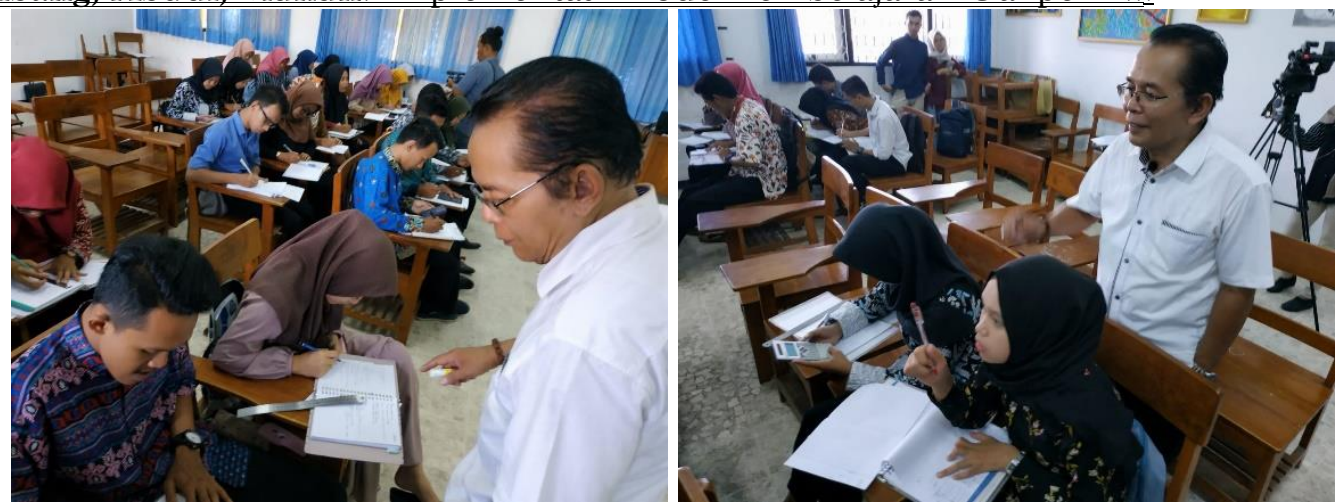

Gambar 5. Dosen Model Melakukan Umpan Balik kepada Mahasiswa

\section{Tahap Lanjutan}
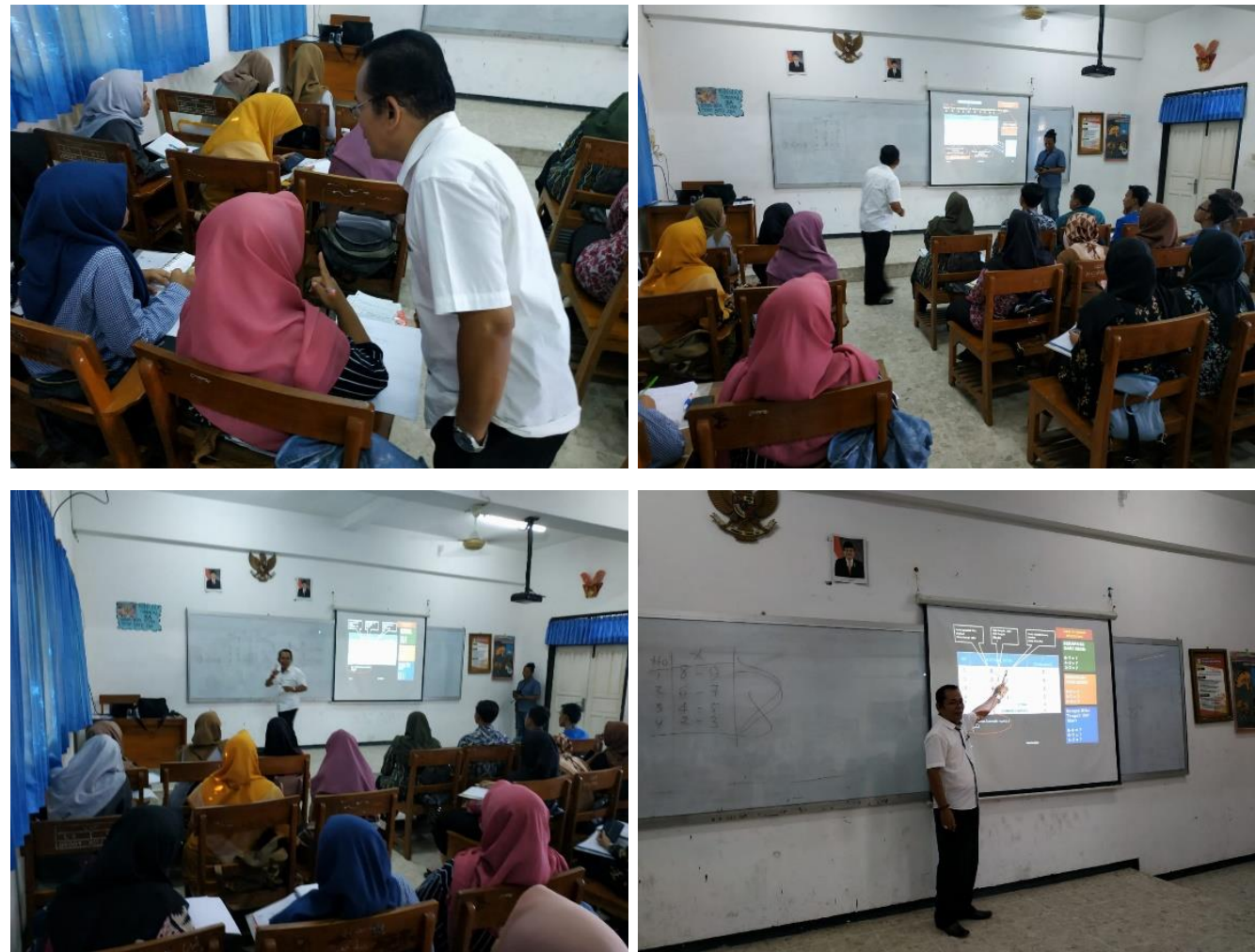

Gambar 6. Dosen Model Memberi Kegiatan Lanjutan Kepada Mahasiswa yang Masih Belum Paham

Tahap ini merupakan tahap lanjutan proses belajar berdasarkan umpan balik. Pada tahap lanjutan ini dosen memberikan kesempatan kepada mahasiswa untuk memperbaiki berbagai hal mengenai konsep yang belum dimengerti. Misalnya mahasiswa belum paham dalam menghitung standar deviasi dalam mata kuliah statistika melalui berbagai cara/rumus, maka dalam tahap lanjutan berarti kembali melakukan orientasi dan dosen akan menerangkan kembali permasalahan yang berkaitan dengan standar deviasi tersebut. 
Bambang, Abdul, Kukuh. Implementasi Model Pembelajaran Gal'perin....

Dengan demikian tahap lanjutan dapat dikatakan sebagai proses ulang, tetapi yang diulang hanya terbatas pada bagian-bagian tertentu yang belum jelas. Dengan tahap lanjutan ini diharapkan hasil belajar mahasiswa semakin meningkat. Selanjutnya jika sudah mecapai penguasaan, maka tahap lanjutan berarti melakukan orientasi pada materi selanjutnya.

\section{Keaktifan Belajar Mahasiswa}

Seperti dilihat pada gambar-gambar sebelumnya, tiap tahapan belajar mahasiswa dianggap cukup aktif. Dimana, diawali dari kegiatan orientasi mahasiswa terlihat cukup aktif mau melakukan kegiatan pemecahan masalah, seperti membuka dan merujuk bukubuku primer dan atau sumber lain sebagai pendukung (literature) yang telah diberitahukan oleh dosen, disamping itu terlihat pula tidak sedikit mahasiswa yang berani bertanya kepada dosen ketika mengalami kesulitan. Ketika diberi kesempatan oleh dosen untuk merefleksikan materi yang telah disampaiakan pada tahap orientasi, tidak menutup kemungkinan juga, sebagian dari mereka bertanya kepada teman yang lebih faham ketika mengalami kesulitan dalam mengerjakan tugas. Secara umun mahasiswa terlibat dalam proses pemecahan masalah.

Ketika pada tahap latihan dan umpan balik, ditemui bahwa, sebagian besar mahasiswa cukup menghargai pendapat dari teman-temannya ketika memberi jawaban atas pertanyaan dari dosen, secara umum, mahasiswa cukup dalam turut ambil bagian dalam mengerjakan soal latihan atau tugas yang diberikan oleh dosen. Mahasiswa aktif memberikan respon pada kegiatan pembelajaran, bersedia mencatat setiap materi yang diberikan, menampilkan ekspresi kesungguhan dalam mengikuti / berpartisipasi aktif dalam pembelajaran, dan memerhatikan atau menyimak jalannya proses pembelajaran yang dibawakan oleh dosen model.

Berdasarkan tabel 5 tentang rekapitulasi data keaktifan belajar mahasiswa, skor rata-rata keaktifan belajar mahasiswa menunjukan di atas skor $\geq 75 \%$ dan dapat dikatakan mahasiswa aktif selama pembelajaran menggunaakan model Gal'Perin. Skor rata-rata keaktifan belajar siswa dari siklus I selalu menunjukkan peningkatan dibanding pertemuan-pertemuan sebelumnya. Skor siklus I mencapai 72 dan siklus II mencapai 79. Grafik peningkatan keaktifan mahasiswa ini juga dapat diamati pada grafik 1. 
Bambang, Abdul, Kukuh. Implementasi Model Pembelajaran Gal'perin...

\section{Kemampuan Berpikir Kritis sebagai Wujud Hasil Belajar Mahasiswa}

Seperti bahasan pada bab pembahasan subbab tahap latihan di atas, diungkap terdapat sejumlah ciri-ciri yang dipandang sebagai indikator kemampuan berpikir kritis, dari ciri poin (a) sampai dengan butir (i). ciri-ciri tersebut akan diekspresikan melalui kesanggupannya mengerjakan tes atau menyelesaikan soal-soal dan melaksanakan tugastugas yang diberikan, karena sangat tidak mungkin melakukan observasi terhadap kemampuan berpikir kritis

Berdasarkan tabel 6 tentang rekapitulasi data kemampuan berpikir kritis sebagai wujud hasil belajar mahasiswa di atas, menunjukkan data bahwa rata-rata hasil belajar siswa menunjukan di atas skor $\geq 75$ atau $\geq$ KKM dan dapat dikatakan baik. Meski tidak signifikan, jumlah mahasiswa yang tidak tuntas mengalami penurunan dari siklus 1 sejumlah 8 mahasiswa (25\%), menjadi sejumlah 7 mahasiswa (22\%) pada siklus 2. Sebaliknya jumlah mahasiswa yang tuntas mengalami kenaikan, dari siklus 1 sejumlah 24 mahasiswa (75\%), menjadi sejumlah 25 mahasiswa (78\%).

Skor rata-rata KBK mahasiswa selalu menunjukkan peningkatan pada tiap siklusnya. Begitu pula persentase ketuntasan klasikal nya menunjukkan peningkatan dibanding pertemuan-pertemuan sebelumnya. Rata-rata KBK sebagai wujud hasil belajar mahasiswa secara klasikal pada siklus 1 sejumlah 79 dan pada siklus 2 sejumlah 82 . Grafik ketuntasan dan ketidaktuntasan, serta grafik peningkatan KBK mahasiswa ini juga dapat diamati pada grafik 2-4.

Setelah dilakukan analisis peningkatan hasil KBK dari siklus 1 dan 2 kemudian dilakukan uji paired t-test untuk memberi keyakinan bahwa ada perbedaan yang signifikan antara hasil KBK pada siklus 1 dan siklus 2. Berikut hasil ujinya

Tabel 7. Hasil Paired Samples Test

\begin{tabular}{|c|c|c|c|c|c|c|c|c|}
\hline & \multicolumn{5}{|c|}{ Paired Differences } & \multirow[t]{3}{*}{$\mathrm{t}$} & \multirow[t]{3}{*}{ df } & \multirow{3}{*}{$\begin{array}{l}\text { Sig. } \\
(2- \\
\text { tailed })\end{array}$} \\
\hline & \multirow[t]{2}{*}{ Mean } & \multirow[t]{2}{*}{$\begin{array}{c}\text { Std. } \\
\text { Deviation }\end{array}$} & \multirow[t]{2}{*}{$\begin{array}{l}\text { Std. } \\
\text { Error } \\
\text { Mean }\end{array}$} & \multicolumn{2}{|c|}{$\begin{array}{l}\text { 95\% Confidence } \\
\text { Interval of the } \\
\text { Difference }\end{array}$} & & & \\
\hline & & & & Lower & Upper & & & \\
\hline Pair 1 Siklus 1 - Siklus 2 & -3.57895 & 14.96777 & 2.42809 & -8.49873 & 1.34084 & -1.474 & 37 & .149 \\
\hline
\end{tabular}

Dari hasil Sig. (2-tailed) sebesar 0,149 yang artinya lebih besar dari 0,05, maka dapat diambil kesimpulan bahwa tidak terdapat perbedaan yang signifikan antara hasil 
Bambang, Abdul, Kukuh. Implementasi Model Pembelajaran Gal'perin....

KBK siklus 1 dan siklus 2. Dari hasil tersebut dapat diartikan bahwa, meski mengalami kenaikan skor KBK dari siklus 1 dan siklus 2 namun tidak memiliki perbedaan yang signifikan.

\section{SIMPULAN}

Sesuai tujuan penelitian ini diketahui bahwa keterlaksanaan pembelajaran oleh dosen model menggunakan model Gal'Perin dikatakan telah $100 \%$ berhasil. Untuk keaktifan mahasiswa menunjukan di atas skor $\geq 75 \%$ dan dapat dikatakan mahasiswa aktif. Skor rata-rata keaktifan belajar siswa dari siklus I selalu menunjukkan peningkatan dibanding pertemuan-pertemuan sebelumnya. Skor siklus I mencapai 72 dan siklus II mencapai 79. Rata-rata KBK sebagai wujud hasil belajar mahasiswa secara klasikal pada siklus 1 sejumlah 79 dan pada siklus 2 sejumlah 82, meski mengalami kenaikan namun tidak menunjukkan perbedaan yang signifikan hal tersebut terbukti dari uji paired t-tes dengan hasil Sig. (2-tailed) sebesar 0,149 yang artinya lebih besar dari 0,05, maka dapat diambil kesimpulan bahwa tidak terdapat perbedaan yang signifikan antara hasil KBK siklus 1 dan siklus 2 .

\section{UCAPAN TERIMA KASIH}

Ucapan terimakasih kami tujukan kepada seluruh pihak yang telah membantu terselesaikannya penelitian ini. Peneliti juga menyampaikan terimakasih kepada Universitas Nusantara PGRI Kediri yang telah memberi dukungan untuk kegiatan penelitian ini, serta pada khususnya kepada Direktorat Pembelajaran, Direktorat Jenderal Pembelajaran dan Kemahasiswaan, Kementerian Riset, Teknologi, dan Pendidikan Tinggi atas hibah Penugasan Dosen di Sekolah (PDS).

\section{DAFTAR RUJUKAN}

Arnyana, I. B. P. 2006. Pengaruh Penerapan Strategi Pembelajaran Inovatif Pada Pelajaran Biologi Terhadap Kemampuan Berpikir Kreatif Siswa SMA. Jurnal Pendidikan dan Pengajaran IKIP Negeri Singaraja. No. 3, Tahun XXXIX (halaman 496-515). 
Bambang, Abdul, Kukuh. Implementasi Model Pembelajaran Gal'perin...

Ariyati, Eka. 2010. Pembelajaran Berbasis Praktikum Untuk Meningkatkan Kemampuan Berpikir Kritis Mahasiswa. Jurnal Matematika dan IPA, Vol. 1 No. 2. (Diunduh 17 Agustus 2019).

Kemmis, S \& Mc Taggart, R. 1992. The Action Research Planner. Australia:Deakin University Press.

Nasution. 2008. Berbagai Pendekatan dalam Proses Belajar Mengajar. Jakarta: Bumi Aksara

Riduwan. 2013. Dasar-dasar Statistika. Bandung: Alfabeta

Rooijakkers, Ad. 1989. Mengajar Dengan Sukses. Jakarta: PT.Gramedia

Siregar, Sofyan. 2012. Statistik deskriptif untuk Penelitian. Jakarta: Rajawali

Soejoeti, Zanzawi. 1985. Buku Materi Pokok Metode Statistik I. Modul 1-5. Jakarta: Karunika

Soenarko, Bambang. 1993. Pengantar Statistika. Kediri: IKIP PGRI Kediri

Splitter, L. J. 1991. Critical Thinking : What, Why, When, and How. Educational Philosophy and Teory 23 (1). 89-109.

Taqwa, Muhammad. 2019. Efektivitas Pembelajaran Dengan Metode Galperin Terhadap Hasil Belajar Matematika Siswa SMA Efektivitas Pembelajaran Dengan Metode Galperin Terhadap Hasil Belajar Matematika Siswa SMA. Jurnal Pendidikan Matematika, Vol. 3 (1), 71-86. (Diunduh 26 Agustus 2019).

Taniredja,Tukiran dkk. 2012. Model-model Pembelajaran Inovatif. Bandung: Alfabeta

USAID. 2014. Praktik yang Baik dalam Pembelajaran di Sekolah Dasar dan Madrasah Ibtidaiyah (SD/MI). Malang: Pelatihan Profesionalitas Dosen

Utomo, Tjipto. Dkk. 1991. Peningkatan dan Pengembangan Pendidikan. Jakarta: PT Gramedia Pustaka Utama 